\title{
Impact of Social Media in Coffee Retail Business
}

\author{
Ersoy Ayse Begum ${ }^{1, ~ *}$, Keceli Yavuz ${ }^{2}$, Kwiatek Piotr $^{3}$ \\ ${ }^{1}$ Department of Marketing, Shannon School of Business, Cape Breton University, Sydney Nova Scotia, Canada \\ ${ }^{2}$ College of Business, Alfred University, New York, USA \\ ${ }^{3}$ Department of Marketing, College of Business, American University of the Middle East, Kuwait City, Kuwait
}

Email address:

Ayse_ersoy@cbu.ca (E. A. Begum)

${ }^{*}$ Corresponding author

To cite this article:

Ersoy Ayse Begum, Keceli Yavuz, Kwiatek Piotr. Impact of Social Media in Coffee Retail Business. Journal of Business and Economic Development. Vol. 5, No. 1, 2020, pp. 44-55. doi: 10.11648/j.jbed.20200501.16

Received: June 18, 2019; Accepted: February 7, 2020; Published: March 17, 2020

\begin{abstract}
Retail coffee business has been growing fast in the Middle East countries particularly during the last decade. High penetration rates of mobile communication devices such as smart phones and high usage of Social Media make the coffee retails in the region with Fee WIFI access, very attractive off-line and on-line social venues. The growth of internet in Arab countries is continuous and offers many e-commerce opportunities for retail businesses to penetrate, grow and achieve loyalty. This article aims to test how coffee retail businesses can optimize social media usage in order to increase their customer base, reach higher level of customer satisfaction and hence increase rate of customer loyalty in the long run. The literature review focuses on social media engagement and use of businesses, small businesses and retailers in the world and in the middle-east, coffee shop industry and coffee shop service expectations of customers. The primary data collection is targeted to test the constructs identified in the secondary data for coffee retail business as well as social media engagement of subjects who frequent coffee shops. Proposed conceptual model suggests that social media engagement of coffee shops customers through retailers' social media and internet presence will lead to higher satisfaction about the shop and consequently transform them into loyal customers. Therefore, finally the model suggests that coffee shops should continuously seek to optimize their social media enabled marketing activities in order to achieve their business objectives.
\end{abstract}

Keywords: Social Media, Social Media Engagement, Small Businesses, Coffee Shop Business, Customer services and Loyalty

\section{Social Media Engagement and Use for Businesses}

In the digital world or our days, firms are using Social Media to effectively reach their customers, capture new ones and implement more targeted loyalty programs. According to a McKinsey report, firms are not only using social media more and more to engage with customers but are making this digital form of brand engagement a high strategic priority [1].

Moreover, recent studies suggest that consumers are increasing their participation in social media, and firms utilise these platforms as sales channels in addition to marketing communication tools [2].

[3] carried out a study involving content analysis of different articles pertaining to social media marketing and optimization by businesses. The study not only focused on how the consumers use social media, but also on the perspective of firms on the usage and the optimization of the platform for business. The results indicated that microblogs and social networks are widely used means by businesses and the sites directly managed by businesses produce better results [3].

[3] Further argued that Social media communication by firms could lead to increase in consumption of the products. However, the strategies to be used on social media channels need to be optimized in accordance with the demographics of the users. According to the authors another important factor is that the messages conveyed in social media activities so should consequent in the improvement of customers attitude towards the brand. Vivid and more interactive posts on the platforms are very instrumental to this end and can be measured by increased number of shares and likes. To this 
end Facebook and Twitter according to the findings under the research are the best means for improving consumer attitudes about the brand.

This brings the discussions to the concept of s-commerce which is defined as a subset of eCommerce that brings eCommerce functionality directly into an established social network to drive sales. Social commerce is a form of commerce that is mediated by social media and is converging both online and offline environments. Social commerce involves using social media that support social interactions and user contributions to assist activities in the buying and selling of products and services online and offline [4].

Marketing through social media platforms, can be fast and powerful way to do the product campaign. Social media marketing programs usually centre on efforts to create content that attracts responsiveness and encourages readers to share it with their social networks. [5] Demonstrated in an article that the main drivers of s-commerce (social media commerce) engagement are message, social media account credibility, peer communication and online social interaction propensity. Influencers and target audiences satisfaction with brands' Facebook and social media activity result in increased intentions to engage in s-commerce activities.

Relationship marketing can certainly not be ignore in all these discussions. As per the Relationship Marketing (RM) theory put forward by [6-7] identified conceptual models that specify a number of antecedents that influence consumer intentions to purchase products and services directly through s-commerce.

Facebook, for example, as the worlds leading Social Networking Site with over 1.6 billion active users across the globe is said to have a significant potential for firms aiming s-commerce activities [8]. Facebook has been actively encouraging consumers to shop via Facebook brand pages through the recent introduction of a range of new ad features leading firms to increasingly attempt to embrace Facebook as a marketing channel to drive consumer engagement, brand awareness and shopping opportunities [9].

Considering the exponential growth of S-commerce and the importance of Social Media engagement of firms and customers, this study examines the dynamics with respect to the Coffee Retail Business with a focus in the Middle East.

Social Media Engagement for Small businesses and retailers

Word of mouth is what the small business owners had to rely on to attract new customers and build a reputation. Since recommendations from existing customer is an important source of customer base extender for small businesses, and the customers today communicate more and more via social media networks, social media is an important source of digital word of mouth for small businesses and retailers.

Although more and more small businesses are using social media, there is not enough understanding of how to adapt and use Social Media for growing business and building loyalty. Insites Consultings 2011 research on firms across US and Europe has revealed that nearly 90 of firms undertake Social Media activities and half of them integrated SM activities in their short term and long term business strategies. The focus of this paper being retailers specific, literature review of retailers integrating SM and S-commerce into their strategic planning is given below.

Reference [10] demonstrated that retailers use social media to engage and interact with their customers hence increasing the dialogue between the retailer and consumers or between consumers. Retailers then can use social media to improve communication and develop interpersonal relationships with consumers. This active and continuous level of engagement will not only promote brand performance but also improve the retailer's performance.

Social media Internet technologies have brought new opportunities as new channels of distribution and communication for small businesses [11]. Socialmedia can be utilized to break through the clutter, and connect with customers on one to one basis [12]. Leibovitz in 2012 further suggested that social media influences consumers purchasind decisions significantly. Firms whose social media presence is of significant visibility achieved enchanced brand recognition and scored higher in search engine ranking [13].

However, one of the critical success-factor is the content development for social media accounts as the more interesting is the content the more engagement and interaction is created with existing and potential customers. Prior studies have shown that peer communication via social media can exert a huge influence on attitudes and purchasing behaviors [14].

The ability of social media to create interactive dialogues with customers is a powerful customer engagement tool [15]. In addition the cost of making a difference in the mind of consumers with personal engagement through social media is significantly lower than traditional media and even generic internet advertising making it the most cost-effective form of information dissemination and customer interaction [14]. Social media is not only an effective communication channel but also a good intermediary to collect information from the customers [16].

As good and as rewarding social media is for small businesses and retailers, it also has some challenges for the business owners. Begin technologically savy is a prerequisite and the time it takes to create social media accounts and keep them current, relevant and interesting. Social media also presents challenges for small businesses. Many small business men and women are not technologically savvy and know little about social media.

\section{Small Businesses in the Middle East}

In the last fifteen years Middle East and particularly the Gulf Region have become as a major retail trading and banking centre for the global market. It is crucial to understand the retail business with particular focus on family owned small businesses.

Islam being in the centre of life in the Gulf Region, needless to mention that Islamic culture shapes the geography and therefore the organizations and managers working there are significantly influenced by the sections related to commercial transactions in the Quran. 
Authoritarian management is predominant in large organizations, while consultative methods prevail in other arenas. Article identified by [17] indicates that smaller, family-controlled firms were less bureaucratic, authoritarian, and impersonal than larger firms that were not family controlled. Some Islamic sects prefer consultative methods of management, which is more consistent with tribalistic traditions [18].

Family owned most small businesses are managed by the elder family members and stress a leading role for the fathers [19]. Satisfying customers remains the top priority for Middle East small retailers which requires thorough understanding of customers' needs and what satisfies them. Family-owned businesses are advantageous on this due to the fact that they can learn about their customers' needs and be more flexible in meeting those needs. References [17, 20, 21] all argue that family businesses have more easy access to understanding customers' needs and wants.

Governments in the Gulf region recognizes the importance of small businesses to the growth of their economies and decreasing dependence on the oil industry. $60 \%$ of GDP in the UAE is contributed by the small businesses in the UAE for example and this number is expected to reach $70 \%$ by 20121 . Considering increasing importance of small businesses in the region, an aggressive and competitive growth plan is now being formulated. However, giving the uncertainty of today' $s$ economic climate, makes this very challenging.

\section{Social Media Engagement and Use for Small Businesses in the Middle East}

Looking at the adoption of social media among small and medium-sized enterprises (SMEs) in the Middle East region; Coffee Shop business in the Middle East, Small businesses are less likely to use emerging technologies due to their limited capabilities, and resources [22-24]. SM usage has been quite extensive in the Arab region contrary to the perception of the West World [25]. LinkedIn analysis into the SM adoption of 260 SMEs in the Gulf Cooperation Council (GCC) found that 92 percent of companies are already on social media platforms, with a further five percent preparing to establish a presence [26].

Needless to mention rapid growth of the SM trend among businesses in the GCC, Social Media has become a crucial part of the marketing strategies. This rapidly accelerating trend among businesses in the GCC has strategically placed SM as an important element in today's comprehensive marketing strategies. [27] argues that because of organisational, cultural and environmental differences, comparison of small businesses adoption of social media in developed and developing countries should not be generalised.

Like in the developed markets, Social Media marketing is a derivative of word of mouth marketing, viral marketing and social presence theory in the Middle East as well [28].

[31] In April 2017 wrote a research article which demonstrated that attitudes of owners/entrepreneurs of SMEs towards SM usage were grounded in their perceptions of the benefits of SM. As long as SM was recognized as an essential platform for branding, advertising, and promoting their products and services, it was considered to be used. Most small businesses use SM to design their advertising materials using rich, dynamic, and interactive media at minimal cost. $\mathrm{SM}$ is an ideal venue to employ viral marketing techniques to build brand awareness for the companies.

Some other findings of the work carried out by [29] Ahmad et all (2017) revealed that SMEs can attract new customers on SM by creating pages that are tailored to the requirements of potential customers by allowing existing customers to share their views on their experiences, thereby enhancing the SMEs goals and targets.

The same study showed that small businesses and retailers can use SM to attract customers to meet other customers as poeple are increasingly utilizing SM for ratings, reviews, and recommendations given by others. This makes the social media a good platform to leverage on community networks and information sharing. SM helps companies to discover who likes or dislikes their products and services and and allows businesses to turn unhappy customers into satisfied and returning customers.

This has led to a new phenomenon known as social contagion. Social contagion can be defined as an event that "occurs when adoption is a function of exposure to other people's knowledge, attitudes, or behaviors" [30]. Social contagion arises when people in a social structure rely on one another to manage uncertainty regarding future purchase decisions [31].

Theoretically speaking, social beings, people, use SM to fulfil their need to connect with others and exchange information more quicklty than any other communication medium. This fact when used appropriately can surely lead to increased sales and enlarge customer base for small retailers [24].

In addition, SM can help businesses drive revenue from existing customers by getting them to spend more on each purchase [32]. For example, giving out coupons at each purchase is commonly used by small retailers in the Middle East. [35] Indicated that the dominant social media platform in the Middle East region is Facebook, with nine out of ten national Internet users using it (90 percent), followed by WhatsApp at 82 percent, and Instagram (56 percent). Twitter comes fourth with the UAE having 51 percent active users in the country, and, finally, YouTube with 50 percent.

\section{Coffee Shop Business in the Middle East}

According to Business Insider, coffee is the second most sought-after commodity in the entire world, with an industry that is worth over $\$ 100$ billion across the globe. 500 billion cups of coffee are consumed on Earth every year. South America ranked as the largest coffee producer, with Brazil producing about 43.2 million bags of coffee. Consumers of coffee are generally aged 19-34 years old and key contributor to the growth of coffee 
consumption is said to be the Millenials. With the rise in urbanization and the demand for quick, quality product has been fueling the expansion of café insustry across the globe [33]. The coffee and snack shops industry is a $\$ 30$ billion market that grew at average annual rates of 2.7 percent between 2009 and 2013, as reported by [34].

According to [8] Starbucks is by far the largest coffee house chain in the world in terms of revenue, generating more than 10 times the revenue of its closest competitor, Costa Coffee, in 2015. According Euromonitor Coffee shops are the fastest growing restaurant category. In 2016, specialist coffee shops were the fastest growing major restaurant category in terms of global sales, increasing 9.1\% from 2014-2015. The growth was steady across the globe in both developed and developing markets. The largest growth opportunities will be in Asia While all regions will see strong growth in the category, Asia Pacific will be home to the largest sales increase in specialist coffee shops, totaling over US\$3.7 billion dollars in new value growth from 2016-2020. Worldwide Competition is growing quickly, leading to rapid diversification. In fact The Coca-Cola Company recently purchased Costa Café.

Competitive dynamics in the coffee shop market are changing at the local level as well. In emerging markets, this has meant an increasingly large number of brands competing for share, many of which are going to creative new heights to differentiate themselves. In addition to international competition, with increased coffee consumption, café retail business in the Middle East also experienced a rapid growth both through international chains and local brands.

Middle East's coffee industry, is expected to climb to $\$ 4.4$ billion by 2021 , according to Euromonitor International. The new movement has seen a shift in consumer appreciation of coffee as an artisan, specialist and quality experience, rather than a commodity. As a beverage with multi-cultural appeal, coffee consumption in the region is growing twice as fast as the global average, putting pressure on the food service industry to stay relevant to customers [35].

Coffee has always been a part of Middle Eastern culture and, in recent years, chains have caught on, opening a flurry of coffee shops in thriving regions like the UAE and Saudi Arabia. Whether local or international only those who will identify satisfy quality seeking customers will survive. The most promising trend to this end seems to be the specialty coffee according to Euro Monitor.

\section{Coffee Shop Customers Service Expectations in the Middle East}

Coffee shop owners/managers can build more effective marketing strategies if they understand factors influencing customers brand involvement and eventually build brand loyalty among them [36].

Reference [37] argued that customers develop loyalty when they show an interest and spend time and energy in choosing a specific coffee shop to frequent. Different from product brand involvement, service brand involvement can be difficult to understand, because of the unique characteristics of the service industry, which are intangible and heterogeneous [38].

A study on coffee shop industry in South Korea by Cha et al in 2015 showed that consumption at a coffee shop can be continuous or occasional; therefore, developing brand loyalty is critical to sustain a long-term customer relationship. Promoting customers' interests and emphasis toward the coffee brands become essential factors for coffee shop brands. It is clear that customer involvement is important because it influences customers' consumption experiences and service process Production and consumption in the service industry are often inseperable and hence customers are encouraged to be involved with service delivery and prefer relevant concepts [39, 40]. Reference [41] in his article has argued that key factors to lead customer service satisfaction for Coffee Shops are Product and Service Innovation, Technology integration. In addition knowledgeable barista, ambiance, no waiting at the cashier and really good coffee are most expected by the consumers [42]. Offering your customers Wi-Fi internet access in your coffee shop is a great extra service. It gives your customers an extra reason to visit your coffee shop and can be arranged without spending a lot of money [43]. Use of loyalty cards and high traffic location are also important factors for the customer to choose your cafe. Loyalty cards are the most cost-effective customer acquisition tactic [44].

Millennials are spending more money on coffee than other generations but prefer higher quality coffee experiences because they choose to spend their money on better life experiences.

\section{Research Methodology}

\subsection{Hypotheses and Research Model}

Based on the literature, we developed the following hypotheses to examine the factors that affect the customers perceived loyalty to their coffee house brand with respect to their social media engagement.

H1: Customers' exposure to the coffee house's on-line ads has a positive impact on the customers' social media expectations from the coffee house.

H2: Customers' purpose of using social media has a positive impact on the customers' social media expectations from the coffee house.

H3: Customers' social media expectations from the coffee house has a positive impact on the customers' behavior of joining/following coffee house's social media account.

H4: Customers' behavior of joining/following coffee house's social media account has a positive impact on the customers' perceived loyalty to the coffee house brand.

H5: Customers' service expectations from the coffee house has a positive impact on the customers' perceived loyalty to the coffee house brand.

\subsection{Research Model}

Figure 1 shows the research model used in this study to 
examine

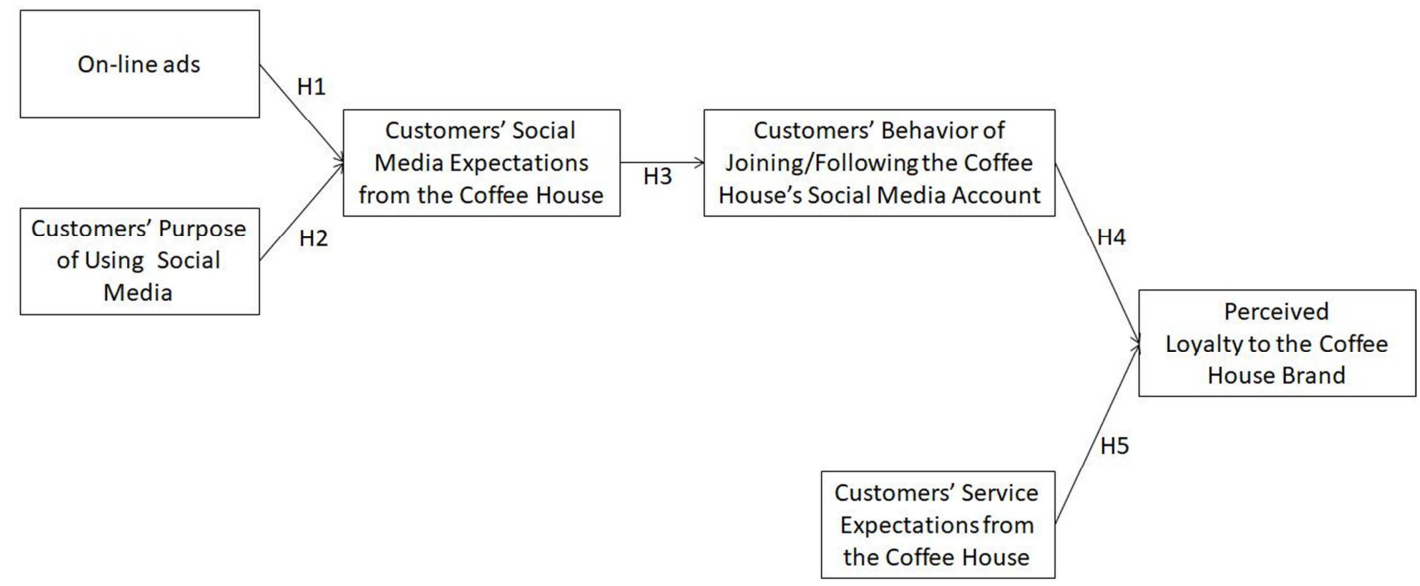

Figure 1. Research Model.

\subsection{Data Collection}

The data was collected through conducting surveys in person at randomly selected coffee shops through convenience sampling during Feb-April 2018. Please refer to Appendix A for the questionnaire.

\subsection{Factor and Reliability Analyses}

In order to check the construct validity of the factors used in the research model, we conducted confirmatory factor analysis (CFA) using psych package in $\mathrm{R}$ environment. This package provides a general-purpose toolbox for experimental psychology, which contains functions like factor analysis, principal component analysis, cluster analysis and reliability analysis [45]. By using the functions in psych package, we calculated the number of factors (with fa. parallel function), we conducted confirmatory factor analysis to calculate the factor loadings (with fa function), and finally we determined the reliability of each factor (with alpha function). Table 1 summarizes the factor loadings and Cronbach's alpha values for each factor.

Table 1. Confirmatory Factor Analysis Statistics.

\begin{tabular}{|c|c|c|c|}
\hline \multirow{2}{*}{ Factor } & \multirow{2}{*}{ Item } & \multicolumn{2}{|l|}{ Factor } \\
\hline & & Loadings & \\
\hline \multirow{4}{*}{$\begin{array}{l}\text { Customers' Social Media } \\
\text { Expectations from the Coffee } \\
\text { House }\end{array}$} & $\begin{array}{l}\text { SMEXPECT; } C R=0.74 ; \text { AVE }=0.65 \\
\text { Coffee houses should have Social } \\
\text { Media activities for their } \\
\text { customers }\end{array}$ & SMExp1 & 0.65 \\
\hline & Coffee houses should create & SMExp2 & 0.82 \\
\hline & attractive content for capturing & & \\
\hline & $\begin{array}{l}\text { Coffee houses should encourage } \\
\text { their customer to use of Social } \\
\text { media account through special } \\
\text { offers }\end{array}$ & SMExp3 & 0.62 \\
\hline \multirow{4}{*}{$\begin{array}{l}\text { Customers' Purpose of Using } \\
\text { Social Media }\end{array}$} & $\begin{array}{l}\text { SMPURPOSE; } \mathrm{CR}=0.67 ; \mathrm{AVE}=0.43 \\
\text { to keep in touch with family and } \\
\text { friends }\end{array}$ & SMPur1 & 0.48 \\
\hline & to get opinions & SMPur3 & 0.48 \\
\hline & to share videos/pictures/music & SMPur4 & 0.61 \\
\hline & to share my experiences & SMPur5 & 0.65 \\
\hline \multirow{4}{*}{$\begin{array}{l}\text { Customers' Service Expectations } \\
\text { from the Coffee House }\end{array}$} & $\begin{array}{l}\mathrm{CHEXPECT} ; \mathrm{CR}=0.74 ; \mathrm{AVE}=0.50 \\
\ldots \text { has a reading/work area that } \\
\text { is specifically designated to be }\end{array}$ & CHExp1 & 0.70 \\
\hline & $\begin{array}{l}\text { quiet and allow customers to work } \\
\ldots \text { has a meeting area designated } \\
\text { to hold events }\end{array}$ & CHExp2 & 0.69 \\
\hline & $\begin{array}{l}\ldots \text { has access to PC and work } \\
\text { stations }\end{array}$ & CHExp3 & 0.74 \\
\hline & $\ldots$ has free access to WIFI & CHExp4 & 0.45 \\
\hline
\end{tabular}

Note: Model fit: $\chi^{2}(87)=127.688, \mathrm{p}=.00 ; \mathrm{CFI}=0.922, \mathrm{TLI}=0.906, \mathrm{RMSEA}=0.050 . \mathrm{AVE}=$ average variance extracted; $\mathrm{CR}=\mathrm{Cronbach}$ 's $\alpha$; $\mathrm{CF}=\mathrm{comparative}$. 
To ascertain the extent to which variances in the constructs could be explained by the model, R2 values of the dependent constructs were calculated and found to be significant. Loadings for each construct, composite scores, and average variance extracted (AVE) per construct are shown in Table 1. The convergent validity of the model is established, since all items are significant at.05 levels and indicate loadings of. 4 or higher [46]. All constructs indicate acceptable levels of reliability with composite reliability measures which range from.66 to.74 [47].

The convergent validity of construct is verified through AVE values above the 0.5 threshold (Fornell and Larcker, 1981). As shown in Table 1, the cutoff AVE value is not achieved for none of the three constructs, with AVE values ranging from. 43 to. 65 . We accept the values based on the notion that if AVE is less than 0.5 but composite reliability is higher than 0.6 , the convergent validity of the construct is still adequate [48].

Table 2. Descriptive statistics.

\begin{tabular}{|c|c|c|c|c|c|c|c|c|}
\hline & Mean & SD & CHExpect & JoinSM & Loyalty & OnlineAd & SMExpect & SMPurpose \\
\hline CHExpect & - & 0.73 & 0.71 & & & & & \\
\hline JoinSM & 1.46 & 0.51 & -0.12 & 1.00 & & & & \\
\hline Loyalty & 1.55 & 0.50 & 0.05 & 0.28 & 1.00 & & & \\
\hline OnlineAd & 1.24 & 0.44 & -0.09 & 0.17 & 0.22 & 1.00 & & \\
\hline SMExpect & - & 0.61 & 0.19 & 0.21 & 0.21 & 0.18 & 0.86 & \\
\hline SMPurpose & - & 0.31 & 0.33 & 0.07 & 0.09 & 0.06 & 0.50 & 0.66 \\
\hline
\end{tabular}

Note: $\mathrm{SD}=$ Standard deviation; the diagonal values represent the square root of the AVE.

Discriminant validity of constructs was assessed through the Fornell-Larcker criterion (Fornell and Larcker, 1981). Discriminant validity cannot be established. Descriptive statistics (the mean, and standard deviation), and correlations are presented in Table 2 (the diagonal values represent the square root of the AVE).

Structural Equation Modelling (SEM)

To test the hypotheses, we developed a Structural Equation Model (SEM) using lavaan package (Rosseel, 2012). The R code to create the model is as follows:

modelsem $<-$ '

CHEXPECT $=\sim$ CHExp $1+$ CHExp $2+$ CHExp $3+$ CHExp4 SMEXPECT $=\sim$ SMExp1 + SMExp2 + SMExp3

SMPURPOSE $=\sim$ SMPur1 + SMPur2 + SMPur3+ SMPur4 + SMPur5

SMEXPECT $\sim \mathrm{h} 1 *$ OnlineAD $+\mathrm{h} 2 *$ SMPURPOSE

JoinSM $\sim \mathrm{h} 3 *$ SMEXPECT

Loyalty $\sim$ h4*JoinSM $+\mathrm{h} 5 *$ CHEXPECT
IND1:=h1*h3*h4

IND2: $=\mathrm{h} 2 * \mathrm{~h} 3 * \mathrm{~h} 4$

IND3: $=\mathrm{h} 3 * \mathrm{~h} 4$

'semmodelfit $<$-sem (modelsem, data=mainData)

summary (semmodelfit, rsquare $=$ TRUE,

standardized $=$ TRUE, fit. measures $=$ TRUE)

First three lines in this model are to calculate the latent variables, second three lines are for developing model by indicating the direct relationships between the factors, and finally the last three lines are to indicate the indirect relationships between the factors. Once the model is defined to an object called modelsem, sem () function uses this object as input and fits the model to another object called semmodelfit. Finally, the summary () function uses the semmodelfit object as input and prints the regression and model fit values. In this model, modelsem and semmodelfit are arbitrary variable names. Table 3 and 4 summarize the SEM regression and model fit values.

Table 3. Structural Equation Modelling Results.

\begin{tabular}{|c|c|c|c|c|c|c|c|}
\hline \multicolumn{2}{|c|}{ Latent Variables: } & \multirow{2}{*}{$\begin{array}{l}\text { Estimate } \\
1.000\end{array}$} & \multirow{2}{*}{ Std. Err } & \multirow{2}{*}{$\begin{array}{l}\text { z-value } \\
-\end{array}$} & \multirow{2}{*}{$\mathbf{P}(>|z|)$} & \multirow{2}{*}{$\begin{array}{l}\text { Std. Iv } \\
0.728\end{array}$} & \multirow{2}{*}{$\frac{\text { Std. al }}{0.682}$} \\
\hline CHEXPECT & CHExp1 & & & & & & \\
\hline & CHExp2 & 1.044 & 0.143 & 7.327 & 0.000 & 0.761 & 0.732 \\
\hline & CHExp3 & 1.027 & 0.143 & 7.184 & 0.000 & 0.748 & 0.697 \\
\hline & CHExp4 & 0.567 & 0.108 & 5.260 & 0.000 & 0.413 & 0.466 \\
\hline \multirow[t]{3}{*}{ SMEXPECT } & SMExp1 & 1.000 & - & - & - & 0.614 & 0.695 \\
\hline & SMExp2 & 0.992 & 0.129 & 7.689 & 0.000 & 0.609 & 0.774 \\
\hline & SMExp3 & 0.975 & 0.142 & 6.865 & 0.000 & 0.599 & 0.622 \\
\hline \multirow{4}{*}{ SMPURPOSE } & SMPur2 & 1.600 & 0.391 & 4.096 & 0.000 & 0.497 & 0.438 \\
\hline & SMPur3 & 1.593 & 0.372 & 4.288 & 0.000 & 0.495 & 0.473 \\
\hline & SMPur4 & 1.572 & 0.322 & 4.880 & 0.000 & 0.488 & 0.608 \\
\hline & SMPur5 & 2.236 & 0.438 & 5.107 & 0.000 & 0.695 & 0.690 \\
\hline \multicolumn{2}{|l|}{ Regressions: } & Estimate & Std. Err & z-value & $\mathbf{P}(>|z|)$ & Std. Iv & Std. all \\
\hline \multicolumn{2}{|c|}{ SMEXPECT $\leftarrow$ OnlineAD $(\mathrm{h} 1)$} & 0.287 & 0.104 & 2.767 & 0.006 & 0.468 & 0.205 \\
\hline \multicolumn{2}{|c|}{ JoinSM $\leftarrow$ SMEXPECT $(\mathrm{h} 3)$} & 0.186 & 0.070 & 2.672 & 0.008 & 0.114 & 0.224 \\
\hline \multicolumn{2}{|c|}{ Loyalty $\leftarrow$ JoinSM $(\mathrm{h} 4)$} & 0.279 & 0.069 & 4.028 & 0.000 & 0.279 & 0.284 \\
\hline \multicolumn{2}{|c|}{ Loyalty $\leftarrow$ CHEXPECT $(\mathrm{h} 5)$} & 0.064 & 0.055 & 1.156 & 0.248 & 0.047 & 0.093 \\
\hline
\end{tabular}




\begin{tabular}{|c|c|c|c|c|c|c|c|}
\hline \multicolumn{2}{|c|}{ Defined Parameters: } & \multirow{2}{*}{$\begin{array}{l}\text { Estimate } \\
0.015\end{array}$} & \multirow{2}{*}{$\begin{array}{l}\text { Std. Err } \\
0.008\end{array}$} & \multirow{2}{*}{$\begin{array}{l}\text { z-value } \\
1.782\end{array}$} & \multirow{2}{*}{$\begin{array}{l}\mathbf{P}(>|\mathbf{z}|) \\
0.075\end{array}$} & \multirow{2}{*}{$\begin{array}{l}\text { Std. lv } \\
0.015\end{array}$} & \multirow{2}{*}{$\begin{array}{l}\text { Std. all } \\
0.013\end{array}$} \\
\hline IND1 & $\mathrm{h} 1 \rightarrow \mathrm{h} 3 \rightarrow \mathrm{h} 4$ & & & & & & \\
\hline IND2 & $\mathrm{h} 2 \rightarrow \mathrm{h} 3 \rightarrow \mathrm{h} 4$ & 0.068 & 0.033 & 2.067 & 0.039 & 0.021 & 0.043 \\
\hline IND3 & $\mathrm{h} 3 \rightarrow \mathrm{h} 4$ & 0.052 & 0.023 & 2.227 & 0.026 & 0.032 & 0.064 \\
\hline
\end{tabular}

Table 4. Model Fit statistics

\begin{tabular}{lll}
\hline Model Fit Statistics & & Values \\
\hline Number of observations & & 184 \\
Estimator & & Maximum Likelihood \\
Model Fit Test Statistic & & 127.688 \\
Degrees of freedom & Minimum Function Test Statistic & 87 \\
P-value (Chi-square) & Degrees of freedom & 0.003 \\
Model test baseline model: & P-value & 628.561 \\
& Comparative Fit Index (CFI) & 105 \\
User model versus baseline model: & Tucker-Lewis Index (TLI) & 0 \\
& Loglikelihood user model (H0) & 0.922 \\
Loglikelihood and Information & Loglikelihood unrestricted model & 0.906 \\
Criteria: & (H1) & -3007.818 \\
& & -2943.974 \\
Number of free parameters & & 32 \\
Akaike (AIC) & & 6079.636 \\
Bayesian (BIC) & & 6182.514 \\
Sample-size adjusted Bayesian & RMSEA & 6081.162 \\
(BIC) & 90 Percent Confidence Interval & \\
Root Mean Square Error of & P-value RMSEA $<=0.05$ & 0.05 \\
Approximation: & & $0.030,0.068$ \\
Standardized Root Mean Square & & 0.467 \\
Residual (SRMR): & 0.067 \\
\hline
\end{tabular}

Our dataset shows an acceptable level of fit to the developed model. Although Chi-square statistic is significant ( $\mathrm{P}=0.003)$, Standardized Root Mean Square Residual (SRMR) Index is 0.067 , which is between acceptable (0.05) and good (0.08) fit limits (Cangur \& Ercan, 2015). Root Mean Square Error of Approximation (RMSEA) Index is
0.05, which indicates good fit. Tucker-Lewis Index (TLI) and Comparative Fit Index (CFI) are 0.906 and 0.922 respectively. Although commonly accepted limits for TLI and CFI are 0.95 , it is assumed that the bigger TLI and CFI values indicate better fit.

Table 5. Lavaan Path Model Results.

\begin{tabular}{llll}
\hline Structural Paths & $\boldsymbol{\beta}$ & $\boldsymbol{z}$-value & Hypothesis \\
\hline OnlineAD $\rightarrow$ SMEXPECT & .29 & 2.77 & H1, supported \\
SMPURPOSE $\rightarrow$ SMEXPECT & 1.32 & 4.48 & H2, supported \\
SMEXPECT $\rightarrow$ JoinSM & .19 & 2.67 & H3, supported \\
JoinSM $\rightarrow$ Loyalty & .28 & 4.03 & H4, supported \\
CHEXPECT $\rightarrow$ Loyalty & .06 & 1.16 & H5, rejected \\
\hline
\end{tabular}

As provided in Table 5, four out five hypotheses are supported by the analysis of the data. First, on-line advertising has a moderate and significant impact on customers' social media expectations from a coffee house $(\beta=.29, p<0.01)$. The customers' purpose of using social media has a strong and significant impact on customers' social media expectations $(\beta=1.32, p<0.01)$. Next, customers' social media expectations from the coffee house have moderate and significant impact on customers' joining and following social media behaviors $(\beta=.19, p<0.01)$. In turn, these social media behaviors have significant impact on perceived customer's loyalty $(\beta=.28, p<0.01)$. Contrary to our expectations, customers' service expectations do not have a significant impact on perceived loyalty $(\beta=.06, p>0.05)$.

\section{Conclusion and Implications for Further Research}

Research results validate the proposed model and shows how on-line advertising and consumer's intent of using social media for socialisation leads to certain expectations from their frequented coffee retailers with respect to their social media presence. The more engaging and interactive the content the more loyalty can be expected.

How a brand makes someone feel is the driver for loyalty or unloyalty. Experiences customers are exposed through products/services are key success factors for further interacting. With respect to social media, content marketing is an effective strategy. Through targeted and intriguing content, it is possible 
to build a positive and rewarding relationship that leads to loyalty. To consistently infuse brand loyalty triggers in your content is to develop and share content that is useful and conveys shared value. Shared value is about focusing more on people and their beliefs and less on your product. The focus on the product is why many contents from brands are ignored.

Retaining and cultivating customer are critically important for coffee outlets due to increasing competition both on local and international levels. Building sustainable relations with customer coffee retail operators can be achieved through creating a high value perception. Perceive superior value will positively influence the customer loyalty. Deep understanding of the consumer can be reflected on customized content through SM which will help the retailer to develop competitive strategies in achieving loyalty.

The findings of this study clearly indicate that having social media account keeping them alive with interactive and engaging customer profile could help building stronger longer relationships with their customers. However perceived loyalty to the Coffee Retailer could not attributed to the customer services of the Coffee House which is questionable in terms of customer relationship principles. Granted, further research is recommended on a more conclusive model identifying other factors influencing customer service expectations and anticipated loyalty and demonstrating the correlation in between.

\section{Appendix}

\section{Appendix A: Survey Questionnaire}

Dear respondent,

You are invited to participate in a person-to- person survey conducted by the Marketing students of the American University of the Middle East on the topic of: 'Social Media Optimization for coffee retail in Kuwait' for the Marketing Research class.

Your participation in this survey is voluntary. You may refuse to take part in the research or exit the survey at any time. You are free to decline to answer any particular question you do not wish to answer for any reason.

Your survey answers are anonymous and no one will be able to identify you or your answers, and no one will know whether or not you participated in the study. The results of the survey will be used for academic purposes only.

Many thanks in advance for your valuable contribution.

Best regards,

Dr. Ayse Ersoy

Asst. Professor of Marketing

American University of the Middle East

Statement of Acknowledgment:

The following is hereby acknowledged;

The anonymity of the person interviewed is guaranteed This survey is only for academic research purposes.

$\begin{array}{lll}\text { Screening Questions } & \text { A } & \text { B } \\ \text { Do you go to Coffee Houses } & \text { Yes } & \text { No } \\ \text { Do you use Social Media } & \text { Yes } & \text { No }\end{array}$

If they answer No to Questions 1 or 2, please thank the respondent and stop the survey.

1. What is your gender?
a. Male
b. Female

2. What is your age?
a. $18-25$
b. $26-40$
c. $41-60$
d. $61+$

3. What is your nationality?
a. Kuwaiti
b. Non-Kuwaiti

4. What is your education?
a. Primary Education
b. High School Graduate
c. Undergraduate Degree 

d. Masters Degree
e. Doctorate Degree

5. Which social media accounts do you use? (you can select more than one)
a. Facebook
b. Instagram
c. Snapchat
d. Twitter
e. LinkedIn
f. Other

6. How many social networking sites communities/groups are you a member of?
a. $3-5$
b. $5-10$
c. $10-15$
d. $15+$

7. How do you access your social network account? (You can choose more than one)
a. PC
b. Laptop
c. Smartphone
d. Tablet

8. How long have you been using social networking sites?
a. 1-3 years
b. 3-5 years
c. 5-10 years
d. 10 years +

9. On average, how much time do you spend daily on a social networking sites?
a. less than 1 hour
b. 1-5 hours
c. 5-10 hours
d. 10 hours +

10. Are you loyal to one specific coffee house brand?
a. yes
b. no

11. Do you prefer local coffee houses over International coffee house chains
a. yes
b. no

12. Do you prefer International coffee house chains over local coffee houses
a. yes
b. no

13. Have you joined the social media account of your favorite Coffee House Brand
a. yes
b. no

14. Have you ever seen any advertising about your favorite coffee house brand in social media 
a. yes

b. no

15. Have you ever followed a blogger that talks about Coffee Houses
a. yes
b. no

16. Have you ever participated to a Coffee house on line promotion
a. yes
b. no

17. When you go to a coffee shop what do you usually purchase?
a. hot drinks
b. cold drinks
c. pasteries
d. sandwiches
e. other

18. When going into a coffee shop what is most important to you?
a. quality of products
b. price
c. location
d. atmosphere/decoration
e. customer profile
f. other

21 I use social media to find information

22 I use social media to play games

23 I use social media to make professional contacts

24 I use social media to keep in touch with family and friends

25 I use social media to make new friends

26 I use social media to get opinions

27 I use social media to share

27 videos/pictures/music

28 I use social media to share my experiences

29 Coffee houses should have Social Media activities for their customers? Coffee houses should create attractive

30 content for capturing and keeping customers

Customers going to the same coffee house

31 should be able to communicate with each other on line

Coffee houses should encourage their

32 customer to use of Social media account through special offers

33 Coffee shops should have their own application

Coffee shops should register with delivery

34 service provider applications like (Coffee, Talabat etc.) 
I would be be inclined to purchase more

35 coffee if If my preferred coffee shop is

having a promotional event (sales, etc.)

I would be interested in a coffee shop that

36

has a reading/work area that is specifically

designated to be quiet and allow customers

to work

I would be interested in a coffee shop that

37 has a meeting area designated to hold

events

38

I would be interested in a coffee shop with

access to $\mathrm{PC}$ and work stations

39

I would be interested in a coffee shop with

free access to WIFI

\section{References}

[1] Brown, B., Sikes, J., \& Willmott, P. (2013, August). Bullish on digital: McKinsey global survey results. McKinsey (Online). Retrieved from http://www.mckinsey.com/businessfunctions/digital-mckin sey/our-insights/bullish-on-digitalmckinsey-global-survey-results.

[2] Hall-Phillips, A., Park, J., Chung, T., Anaza, N. and Rathod, S. I (heart) social ventures: Identification and social media engagement. Journal Of Business Research. Vol. 69 Issue 2. 2016.

[3] Alves, H., Fernandes, C., \& Raposo, M. (2016). Social media marketing: A literature.

[4] Wang, Chingning \& Zhang, Ping. (2012). The Evolution of Social Commerce: The People, Business, Technology, and Information.

[5] Bianchi, C., Andrews, L., Wiese, M., \& Fazal-E-Hasan, S. (2017). Consumer intentions to engage in s-commerce: a cross-national study. Journal of Marketing Management, 33 $(5 / 6)$, 464-494. https://doi.org/10.1080/0267257X.2017.1319406.

[6] Morgan, R. M., \& Hunt, S. D. (1994). The commitment-trust theory of relationship marketing. Journal of Marketing, 58 (3), 20-38. doi: $10.2307 / 1252308$.

[7] Sheth, J. N., \& Parvatiyar, A. (1995). Relationship marketing in consumer markets: Antecedents and consequences. Journal of Academy of Marketing Science, 23 (4), 255-271. doi: 10.1177/009207039502300405.

[8] Statista. (2015). Number of monthly active Facebook users worldwide as of 4th quarter 2015 (in millions). Retrieved from http://www.statista.com/statistics/264810/number-of-monthlyactivefacebook-users-worldwide.

[9] Malhotra, A., Malhotra, C. K., \& See, A. (2013). How to create brand engagement on Facebook. MIT Sloan Management Review, 54 (2), 18-20.

[10] Rapp, A., Beitelspacher, L., Grewal, D., \& Hughes, D. (2013). Understanding social media effects across seller, retailer, and consumer interactions. Journal of the Academy of Marketing Science, 41 (5), 547-566. https://doi.org/10.1007/s11747-0130326-9 review and implications. Psychology \& Marketing, 33 (12), 1029-1038.

[11] Sahay, A., Gould, J. and Barwise, P. (1998), "New interactive media: experts' perceptions of opportunities and threats for existing businesses", European Journal of Marketing, Vol. 32 Nos 7/8, pp. 616-628. [Link], [Google Scholar] [Infotrieve].

[12] Block, R. (2011), Social Persuasion: Making Sense of Social Media for Small Business, Block Media, Fairfax, VA. [Google Scholar].

[13] Wood, C. (2009), "The power of social media: from bolt-on to the centre of the universe", The Hospitality Review, Vol. 8 No. 3, pp. 18-19. [Google Scholar] [Infotrieve].

[14] "Wang, X., Yu, Y. and Wei, Y. (2012), "Social media peer communication and impacts on purchase intentions: a consumer socialization framework", Journal of Interactive Marketing, Vol. 26 No. 4, pp. 198-208. [Crossref], [ISI], [Google Scholar] [Infotrieve".

[15] Van Noort, G., Voorveld, H. and Van Reijmersdal, E. (2012), "Interactivity in brand websites: cognitive, affective, and behavioral responses explained by consumers' online flow experience", Journal of Interactive Marketing, Vol. 26 No. 4, pp. 223-234. [Crossref], [ISI], [Google Scholar] [Infotrieve].

[16] Chung, J. and Buhalis, D. (2008), "Information needs in online social networks", Information Technology and Tourism, Vol. 10 No. 4, pp. 267-282. [Crossref], [Google Scholar] [Infotrieve].

[17] Kets de Vries, M. F. R. (1993). The dynamics of familycontrolled firms: The good news and the bad news. Organizational Dynamics, Winter, 59-71.

[18] Ali, A. J. (1990). Decision-making style, individualism, and attitudes toward risk of Arab executives. International Studies of Management and Organization, 23 (3), 53-73.

[19] Abbasi, S., \& Hollman, K. (1993). Business success in the Middle East. Management Decisions, 31 (1), 55-60.

[20] Chua, J., Chrisman, J. and Sharma, P. Defining the Family Business by Behavior. Entrepreneurship Theory and Practice. July 1999.

[21] Stockdale, R., Ahmed, A., Scheepers, H., 2012. Identifying business value from the use of social media: an SME perspective. In: Proceedings of Information System Innovation in Pacific Asia, Pacific Asia Conference on Information Systems (PACIS), 11-15 July, Ho Chi Minh City, Vietnam. 
[22] Zeiller, M. and Schauer. B. Adoption, motivation and success factors of social media for team collaboration in SMEs. 2011. Retrieved from https://www.semanticscholar.org/.

[23] A. Kaplan, M. HaenleinTwo hearts in three-quarter time: How to waltz the social media/viral marketing dance.

[24] Klischewski, Ralf. From E-Government Strategy to Services: Challenges of Inter-organizational IT Governance in Egypt. Conference Paper. ICEGOV 2014 Portugal.

[25] Straub, D., Hoffman, D., Weber, B. and Steinfeld, C. Toward New Metrics for Net-Enhanced Organizations. 2002. Retrieved from www.dhi.ac.uk.

[26] Liang, J., Ekinci, Y., Occhiocupo, N., Whyatt, G., 2013. Antecedents of travellers' electronic word-of-mouth communication. J. Market. Manage. 29 (5/6), 584-606.

[27] Whitler, K. Why Word of Mouth Marketing Is The Most Important Social Media. July 2014. Retrieved from www.forbes.com.

[28] Syed, Ahmad., Ahmad, N. and Bakar, R. Reflectins of entrepreneurs of small and medium-sized enterprises concerning the adoption of social media and its impact on performance outcomes: Evidence from the UAE. Telematics and Informatics. Vol 35 Issue 1 April 2018.

[29] C. Van den Bulte, S. Wuyts, M. G. Dekimpe, E. Gijsbrechts, R. PietersOpportunities and challenges in studying consumer networks.

[30] R. Goffee, G. JonesWhy should anyone be led by you?Harvard Bus. Rev., 78 (5) (2000), pp. 63-70.

[31] J. L. Munger, D. GrewalThe effects of alternative price promotional methods on consumers' product evaluations and purchase intentions.

[32] Arab Social Media Report 2015, 2015. Retrieved from http://www.arabsocialmediareport.com/News/index.

[33] Menke., A. The Global Coffee Industry. 2018. Retrieved from https://globaledge.msu.edu/blog/post/55607/the-global-coffeeindustry.

[34] IBISWorld. Industry Market Research, Reports and Statistics. Retrieved from https://www.ibisworld.com/.

[35] (https://www.emirates247.com).
[36] Parasuraman, A., Zeithaml, V., and Berry, L. A Conceptual Model of Service Quality and its Implication for Future Research (SERVQUAL). Journal of Marketing Vol29 pp 4150. 1985.

[37] Hochgraefe, C., Faulk, S., and Vieregge, M. Links Between Swilss Hotel Guests' Product Involvement and Brand Loyalty. Journal of Hospitality Marketing and Management. Vol 21. 2012 Issue 1.

[38] Lovelock, C. and Gummesson, E. Whither Services Marketing?: In Search of a New Paradigm and Fresh Perspectives. Journal of Service Research. Vol 7 Issue 12004.

[39] Kinard, B. and Capella, M. Relationship Marketing: the Influence of Consumer Involvement on Perceived Service Benefits. Journal of Services Marketing. ISSN: 0887-6045. 2006.

[40] Lundkvist, A. and Yakhlef, A. (2004). Customer involvement in new service development: a conversational approach. Managing Service Quality: An International Journal, 14 (2/3), pp. 249-257.

[41] RIZEA, R.-D., SARBU, R., \& CONDREA, E. (2014). How Coffee Companies Can Stay Competitive. SEA: Practical Application of Science, 2 (1), 510. Retrieved from http://ezproxy.aum.edu.kw/login?url=http://search.ebscohost.c om/login.aspx?direct $=$ true $\& d b=e d b \& A N=101100612 \&$ site $=e$ ds-live \&scope $=$ site.

[42] (www.silverchef.ca).

[43] (www.howtostartacoffeeshop.co.uk).

[44] (www.forbes.com).

[45] Revelle, W. R. (2017). psych: Procedures for Personality and Psychological Research. Retrieved from https://CRAN.Rproject.org/package $=$ psych.

[46] Fornell C., and Bookstein, F. Two Structural Equation Models: LISREL and PLS Applied to Consumer Exit-Voice Theory. Journal of Marketing Research. Vol 19. Issue 4. 1982.

[47] Nunnally, Jum C. (1967), Psychometric Theory, 1 st ed., New York: McGraw-Hill. (1978), Psychometric Theory, 2d ed., New York: McGraw-Hill.

[48] C. Fornell and D. F. Larcker (1981). Evaluating structural equation models with unobservable variables a measurement error. Journal of Marketing Research 18 (1), 39-50.

0. 